\title{
Female connection method: using a social network approach to genealogical research in the search for the mother of Margaret Champion
}

Received: 7 August 2018

Accepted: 5 October 2018

KEYWORDS: Christian Zimmerman; FAN method; female connection method; Margaret Champion; social network

\section{Stephen B. Hatton}

\begin{abstract}
The search for Margaret Champion's mother is accomplished using two approaches. The first employs the FAN (friends, associates, neighbors) method and direct evidence. Associates in eighteenth-century America (and elsewhere and in other eras) were predominantly male because it was overwhelmingly males who participated in transactions and organizations that indicated association. A brief consideration of some of the philosophical and sociological theories of feminism, however, shows the critical role of women in connecting families together over time and binding family units united in marriage. Often male FAN associations were dependent on female connections. Thus, the second approach combines the female connection method and direct evidence. In some cases, this method not only leads to solutions to practical genealogical problems but also explains the reasons families were networked.
\end{abstract}

\section{Introduction}

It is often more difficult to do genealogical research for female than for male ancestors and research subjects. Among the reasons are that women in many countries and cultures did not retain their birth surnames after they were married, and that various laws and customs prevented or limited their participation in business, legal, and political transactions, the documents of which often provide genealogical evidence. Not only do these and other obstacles make it difficult to learn biographical details about women, but in many cases they also increase the challenge of discovering who their fathers were and especially who their mothers were. Such genealogical problems can frequently be solved with a combination of direct and indirect evidence (to answer questions that have been well thought out, designed to advance incrementally toward the solution). One useful and increasingly used approach is cluster analysis, or the FAN (friends, associates, neighbors) method. ${ }^{1}$ Researching an ancestor's friends, associates, and neighbors may lead to discovery of evidence that enables one to overcome obstacles that one encounters when focusing solely on the ancestor. Another approach is to use what may be called the female connection method, which focuses on the role of women as the cohesive force in intra- and inter-family networks. The female connection method illustrated in this case study is a social network approach that depends on the critical role women play in creating, maintaining, and relating stories about extended families, particularly those interlinked by multiple marriages.

This case study illustrates both approaches. Its research subject is Margaret Champion who lived in Pennsylvania and Ohio in the United States, and who died in Ohio in 1843. She was chosen for this case study because she served a pivotal role in her extended family. The genealogical research goal is to learn who her mother was. The article opens with establishing who her father was. Beginning the search in Huntingdon County, Pennsylvania, it first uses a combination of clues gathered from direct evidence and the FAN method. After achieving the end goal of identifying her mother, the article next illustrates how the problem is also solved using the female connection method without the FAN method. Of course, these two methods may be used together to bolster the proof argument.

\section{Margaret Champion}

When Christian Zimmerman ${ }^{*}$ wrote his undated will in Huntingdon County, Pennsylvania, he named Margaret Champion as one of his children. ${ }^{2}$ It was written between 1803 (it mentions daughter Sarah who was born in about 1803) ${ }^{3}$ and 7 November 1805 (when the will was proved). ${ }^{4}$ The will did not specify who Margaret's husband was, but referred to Zimmerman's plantation "where John Champion now lives," strongly suggesting

*Spellings of names will vary throughout the article to reflect the spelling in the relevant source being discussed. 
that he was her husband. That is because John was the only male Champion named in the will and was living on Zimmerman's land. ${ }^{5}$ Research confirms the marriage through indirect evidence. James Champion (John's father) ${ }^{6}$ and John Champion were the only Champions enumerated in Huntingdon County in the 1800 U.S. census (John is listed immediately after James). ${ }^{7}$ James Champion's will, written in Beaver County, Pennsylvania, refers to money owed to him by people living in Huntington [sic] County, and he bequeaths money to John. ${ }^{8}$ John Champion later moved to Richland County, Ohio where he died on 10 August $1826 .^{9}$ He was buried in Hanna Cemetery near Tiro, Crawford County, Ohio. ${ }^{10}$ John Champion's will refers to his unnamed widow. ${ }^{11}$ She died on 27 January 1843 and was buried in the same cemetery immediately next to John Champion, ${ }^{12}$ identified on her gravestone as "Mary M. wife of John Champion."13 Margaret or a non-anglicized form of Margaret must have been her middle name (or German call name). The gravestone reads "in the 62d year of her age," which implies she was sixty-one, but for various reasons (informant error in a statement or calculation, engraver error, misuse of the phrase) such phrases were sometimes inaccurately used to mean attainment of the designated age - in this case, sixty-two. One can tentatively believe her age at death was sixty-one or sixty-two.

Christian Zimmerman's last will and testament refers to his wife Margaret. ${ }^{14}$ Despite their shared given names, one should not assume that his widow was the mother of Margaret (Zimmerman) Champion. Three of Christian Zimmerman's five daughters (Margaret Champion, Elizabeth Molholon, and the deceased Catherine Crosby) ${ }^{15}$ had married, and a fourth, Christiana, was unmarried ${ }^{16}$ but at least fourteen years old as of about $1808 .{ }^{17}$ The fifth daughter, Sarah, was a minor born in about 1803 (she was about five in 1808)..$^{18}$ Though it is possible that Christian's widow Margaret was the mother of three married daughters, Christiana, and a child two years old at the time of Christian Zimmerman's death, the large age gap between Christiana and Sarah suggests that she may not have been the mother of Margaret (Zimmerman) Champion or her older siblings (Figure 1).

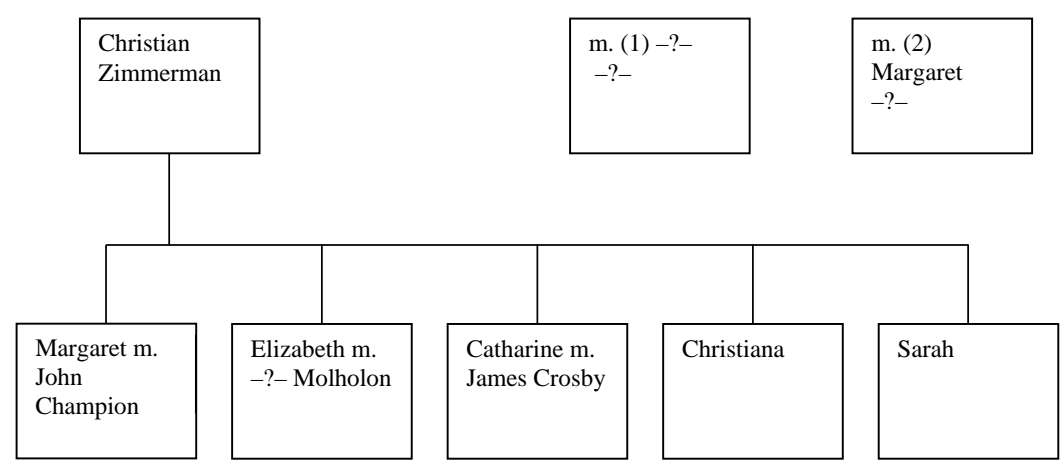

Figure 1. Christian Zimmerman's children.

\section{With FANfare}

Numerous clues in Huntingdon County help prove identity across geographic locations, and lead to the discovery of Margaret (Zimmerman) Champion's mother.

- Christian Zimmerman married Margaret -?-.

- In 1805, Christian had three married daughters named Margaret, Elizabeth, and Catharine (Catharine predeceased Christian).

- He had another daughter named Christiana Zimmerman (unmarried as of about 1805). ${ }^{19}$

- His youngest child was Sarah, born in about $1803 .^{20}$

- He lived in Morris Township, Huntingdon County. ${ }^{21}$

- Before his 1798 purchase of land in Huntingdon County, he lived in Londonderry Township, Dauphin County, as indicated in the deed of purchase: "the said William Davis ... did relinquish his said purchase unto Christian Zimmerman of Londonderry Township in Dauphin County." 22 This provides the place to continue the search for pre-Huntingdon County records.

A search for Huntingdon County record sources related to Christian Zimmerman reveals a number of associates worth researching to determine if they were acquaintances prior to his move there. Excluding those who were only neighbors, the following were some of his associates.

- John Montgomery, who witnessed Christian Zimmerman's will, ${ }^{23}$ was the guardian of Zimmerman's grandchildren who were the children of daughter Catharine Crosby, ${ }^{24}$ and was listed three names before Christley Simmerman in the 1800 census. $^{25}$

- James Stewart (Christian bought land from him and three other heirs of John Stewart) ${ }^{26}$ was listed two names after Christian in the 1800 census. $^{27}$

- David Stewart, who was one of the four heirs from whom Christian bought land, ${ }^{28}$ witnessed Christian's will, ${ }^{29}$ and was listed twenty-one names after Christian in the 1800 census. $^{30}$ 
- Jacob Weitzel/Whitzel (one of the four from whom Christian bought land [Weitzel's wife was a daughter of John Stewart]) ${ }^{31}$ was listed three names after Christian in the 1800 census. $^{32}$

Research about these four men did not lead to any credible evidence that Christian Zimmerman knew them before he arrived in Huntingdon County. Other associates are more promising for helping to backtrack Christian's earlier life in an attempt to identify his older children's mother.

- Frederick Kuhn purchased land in partnership with Christian Zimmerman. ${ }^{33}$ In 1801, Zimmerman executed an indenture transferring the property to Kuhn. ${ }^{34}$ Those close business transactions may indicate a prior relationship. Frederic Kuhn is listed forty names after Zimmerman in the 1800 census. $^{35}$

- Christian Harnish was a co-executor of Zimmerman's will. ${ }^{36}$ He was not listed in the 1800 census in Huntingdon County, but Tobias Harness was listed two names before Frederic Kuhn. ${ }^{37}$ Their proximity and common surname suggest a possible relation between them.

- Michal Kellar was the second co-executor of Zimmerman's will. ${ }^{38}$ Michael Keller was listed between Tobias Harness and Frederic Kuhn in the 1800 census. ${ }^{39}$ The conjunction of actions and specific residences may indicate a cluster of relations.

- John Keller Sr. was appointed the guardian of Zimmerman's minor child, Sarah. ${ }^{40}$ John Keller appears immediately after Frederic Kuhn in the 1800 census. ${ }^{41}$ This dual concurrence may signal a relationship.

It cannot be determined from Huntingdon County records exactly when these men first appeared there. The earliest date found for Christian Zimmerman is his 30 June 1798 purchase of land. ${ }^{42}$ However, the deed leaves open the possibility that he arrived earlier when it refers to William Davis relinquishing that land to Zimmerman on some unspecified but probably recently prior date. William Davis purchased land from John Stewart, and then after John Stewart's death and with the agreement of John Stewart's heirs, relinquished the purchase to Christian Zimmerman. ${ }^{43}$ That his residence was listed in the deed as in Dauphin County suggests a recent arrival in Huntingdon County. Zimmerman does not appear in the U.S. direct tax of 1798 for Huntingdon County. The earliest recorded Huntingdon County date for John Keller is 2 August 1797, when one of his horses was stolen. The advertisement announcing this news reportedly appeared in the 8 August 1797 issue of the Huntingdon Courier and Weekly Advertiser. ${ }^{44}$

\section{Dauphin and Berks Counties}

The specification of Londonderry Township, Dauphin County as Christian Zimmerman's residence prior to Morris Township, Huntingdon County leads to research there. Records in Dauphin County confirm that Christian Zimmerman lived there prior to moving to Huntingdon County. He was subject to militia duty in Dauphin County (formed in 1785 from Lancaster County) from 1786 to 1789 , appearing on Londonderry Township return rolls. ${ }^{45}$ He was taxed in Londonderry Township, Dauphin County, between 1785 and $1793 .{ }^{46}$ A church record there documents his marriage. He married Margaret Schellenberger on 15 December 1794, in the Evangelical Lutheran congregation of the union church in Campbelltown, Londonderry Township, Dauphin County. ${ }^{47}$ She was not the mother of Margaret (Zimmerman) Champion, who was already married to John Champion when Christian Zimmerman's will was proved in 1805. John and Margaret Champion had a son, Christian Champion, who was born on 4 May 1802..$^{48}$ (According to his gravestone he died on 12 December 1868 at age 66 years 7 months 8 days.) A family Bible records his birthdate as 11 May $1802 .{ }^{49}$ This birthdate indicates that John and Margaret likely married no later than 1801 , seven years after Christian Zimmerman married Margaret Schellenberger.

Margaret Schellenberger was the baptismal sponsor for Elizabeth, daughter of Peter Steffy and Maria Elizabeth, on 31 July 1780 at Muddy Creek Church in Cocalico Township, Lancaster County. ${ }^{50}$ She was also the baptismal sponsor of Salome Less after 2 July 1792 at the Swamp Reformed Church in Cocalico Township, Lancaster County ${ }^{51}$ (see Figure 2).

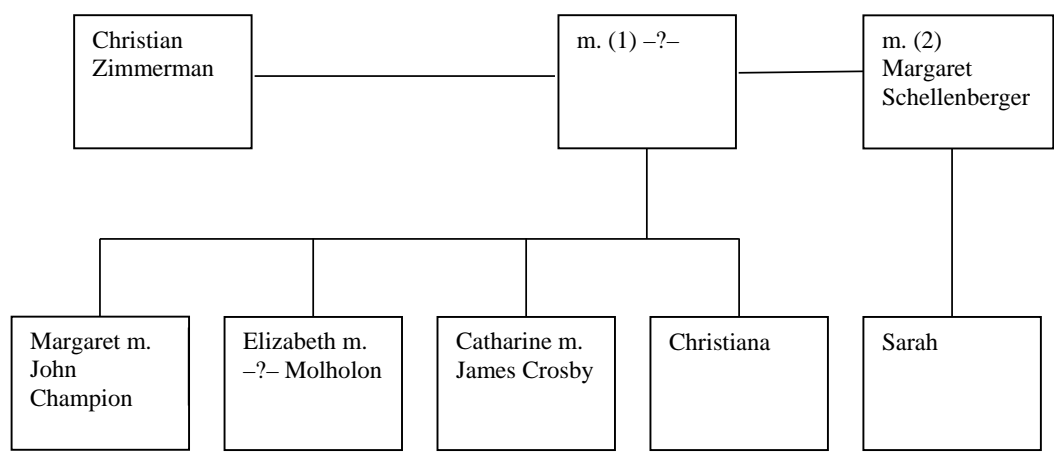

Figure 2. Christian Zimmerman's children assigned to one known and one unknown wife. 


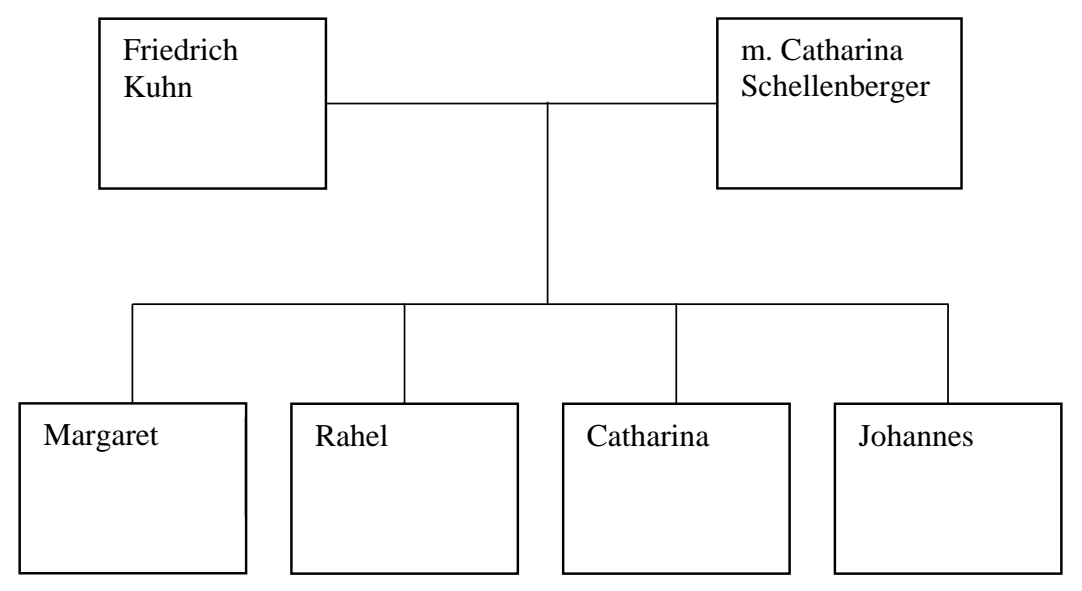

Figure 3. Friedrich Kuhn family.

Friedrich Kuhn and Catharina Schellenberger married on 8 December 1789, in Trinity Lutheran Church in Reading, Berks County. ${ }^{52}$ The marriage of a close associate of Christian Zimmerman to a woman with the same surname as Zimmerman's wife raises the distinct possibility that the two women were related. Kuhn was identified in the marriage record as the third son of Friedrich Kuhn of Cumru Township, Berks County. ${ }^{53}$ Catharina was identified in the marriage record as the youngest daughter of Michael Schelleberger, also of Cumru Township. ${ }^{54}$

Friedrich Kuhn and his wife Catharina had several children baptized in churches located in Heidelberg and Exeter townships of Berks County (see Figure 3).

- Anna Margaretha was born on 3 May 1791, baptized on 15 May 1791 in St. John's (Hain's) Reformed Church in Heidelberg Township, Berks County, and sponsored by Margaret Schellenberger, another association of Catharina and Margaret. ${ }^{55}$

- Rahel was born on 30 January 1793, baptized on 9 June 1793 in Trinity Lutheran Church in Reading, Berks County, and sponsored by Rahel Adamin. ${ }^{56}$

- Catharina was born on 2 November 1794, baptized on 3 May 1795 in Schwartzwald Reformed Church in Exeter Township, Berks County, and sponsored by the parents of the infant. ${ }^{57}$

- Johannes was born on 21 September 1796, baptized on 9 February 1797 in Schwartzwald Reformed Church, and sponsored by Johannes Germant and his wife, Anna Barbara. ${ }^{58}$ The baptismal date suggests that Frederick Kuhn did not move to Huntingdon County before 1797 .

Catharina (Schellenberger) Kuhn's father, whose full name was Johannes Michael Schellenberger, died in 1800. His will, written on 16 May 1800 and proved on 16 July 1800, names his surviving children. ${ }^{59}$ They were Philip, John, Jacob, Elizabeth wife of Peter Steffy, Margaret wife of Christian Zimmerman, Christina wife of Mark Garner, and Catharina wife of Frederick Kuhn (see Figure 4). This explains why Margaret

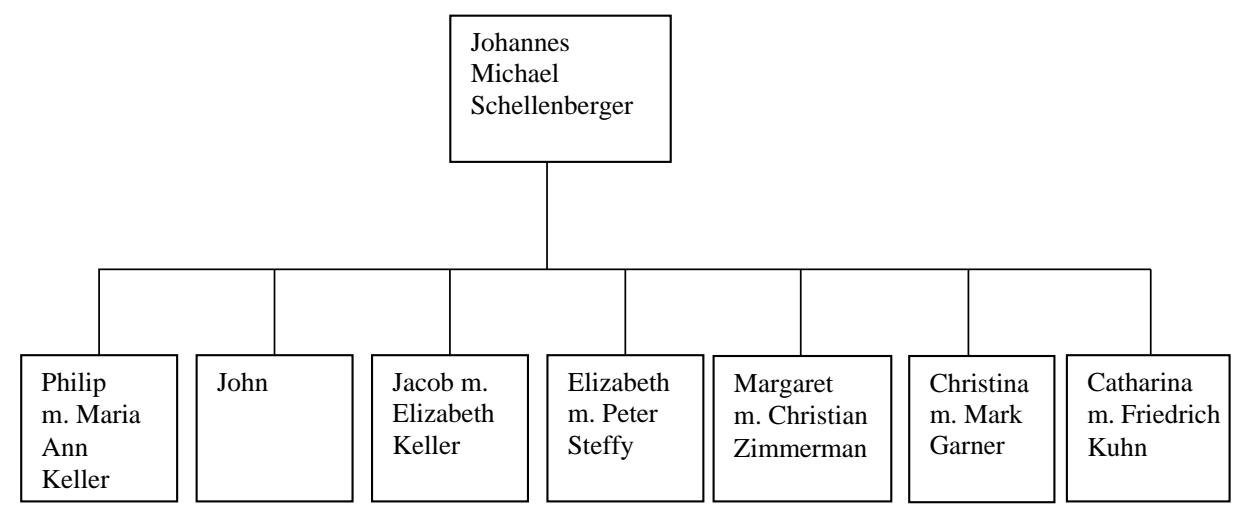

Figure 4. Johannes Michael Schellenberger's children. 


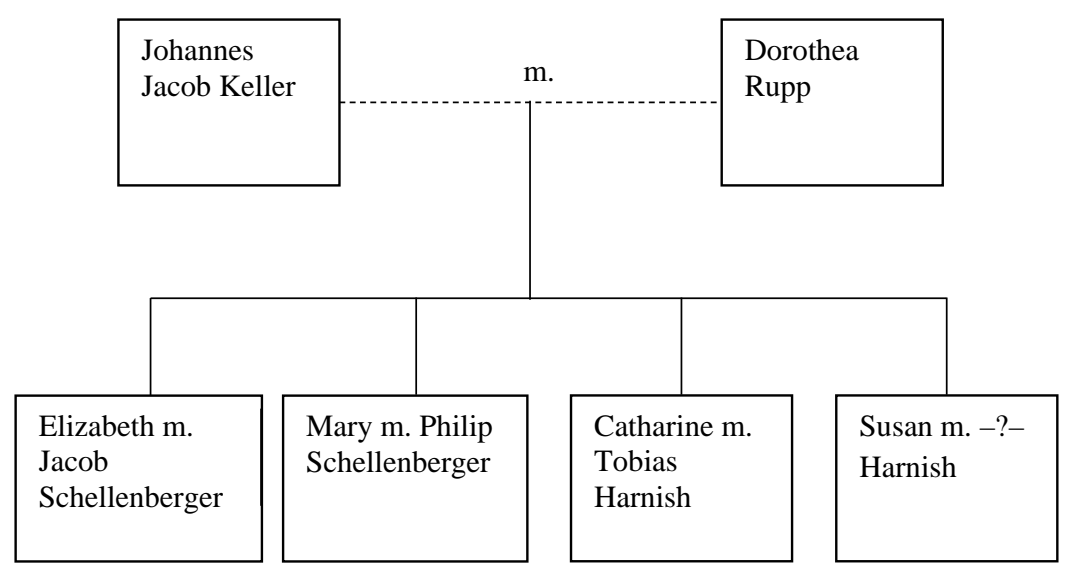

Figure 5. Johannes Jacob Keller family.

Schellenberger was the baptismal sponsor for Elizabeth Steffy and for Anna Margaretha Kuhn. The wives of Christian Zimmerman (Margaret), Peter Steffy (Elizabeth), and Frederick Kuhn (Catharina) were sisters. Christian Zimmerman and Frederick Kuhn purchased land as partners but also as brothers-in-law by marriage. Those two men were closely connected because they married sisters. Johannes Michael Schellenberger's will further specifies that daughter Margaret Zimmerman had no legal issue. Thus, as of 1800, Margaret (Schellenberger) Zimmerman had no children, further corroborating that Christian's four older daughters' mother was not Christian Zimmerman's widow, Margaret.

The Huntingdon County association of Christian Zimmerman with the Kellers was also through marriage. Philip Schellenberger, named in his father's will, married Maria Anna Keller. John Keller referred in his will to daughter Mary Schelleberger. ${ }^{60}$ Michael Shellenberger referred to son Philip in his will. ${ }^{61}$ Philip Shelleberger lived in Huntingdon County in $1800 .{ }^{62}$ Anna Maria Shellenberger was buried in 1832 in Keller Church Cemetery in Huntingdon County (now Blair County). ${ }^{63}$ It appears that Philip Shellenbarger moved to Richland County, Ohio, where he was counted in the 1840 census, ${ }^{64}$ and buried. ${ }^{65}$ Jacob Schellenberger, also named in his father's will, married Elizabeth Keller at Trinity Lutheran Church in Reading, Pennsylvania on 14 December $1794 .^{66}$

Elizabeth and Maria Anna were daughters of Johannes Jacob Keller, most often called John, following American practice rather than the usual German custom of using the second given name as the call name (see Figure 5). Elizabeth was born on 2 July 1773, and baptized on 11 July 1773 by the Rev. John Waldschmidt of Lancaster County. ${ }^{67}$ Maria Anna's baptism has not been found. Thus, two Schellenberger brothers married two Keller sisters.

When John Keller wrote his will on 10 March 1825, he named among his children, Elizabeth Shelleberger, Mary Shelleberger, Catharine Harnish, and Susan Harnish. ${ }^{68}$ Thus there was also a familial connection between the Schellenbergers and the Harnisches through marriage. Catherine, or Anna Catharina Keller, reportedly married Tobias Harnish, ${ }^{69}$ a brother of Christian Harnish (both were sons of Samuel Harnisch). ${ }^{70}$ The German will of Samuel Harnish, proved on 1 July 1788, names "Sohn Christian [son Christian]" and "Söhne Jacob und Tobias [sons Jacob and Tobias]." ${ }^{71}$ Tobias Harnish and Catharine, wife of T. Harnish, are buried in the Keller Church Cemetery. ${ }^{72}$ Christian Zimmerman's Huntingdon County associates Frederick Kuhn, Christian Harnish, and John Keller were related through marriages. The close association of Christian Zimmerman with Kuhn, Harnish, and Keller in Huntingdon County was founded on family connections through marriages made in their previous places of residence. They moved from Dauphin and Berks counties to Huntingdon County, where they continued to associate with each other.

\section{Huntingdon County revisited}

Revisiting the records of Huntingdon County, one finds the interrelationship network more extensive than previously noted when initially examining associates there. John Keller Sr. lived there, having arrived by 1797 . He died there no later than 1831 (his will was written on 10 March 1825, and proved on 22 March 1831). ${ }^{73}$ Some of his children, as well as Schellenberger siblings, also lived there:

- Margaret Schellenberger had married Christian Zimmerman. Christian was there by 1798 when he purchased land. He was listed as Christley Simmerman in the 1800 census. $^{74}$ 
- Maria Elizabeth Schellenberger had married Peter Steffey/Steffen. ${ }^{75}$ In the 1800 census, Peter Staffey was listed in Tyrone Township which bordered Morris Township to the west. ${ }^{76}$ His will, written on 23 April 1833 in Frankstown Township, was proved on 24 January 1840, in Huntingdon County. In the will, he named his wife as Mary Elizabeth. ${ }^{77}$

- Catharina Schellenberger had married Frederick Kuhn. He arrived no earlier than 1797 (date of a son's baptism in Berks County) and not after 1801 (when he received land from Zimmerman in Huntingdon County). He died on 30 September 1837, and was buried in Shaffersville Cemetery in Shaffersville, Huntingdon County. ${ }^{78}$

- Philip Schellenberger had married Maria Anna Keller, and was listed as Philip Shelleberger in the Morris Township, Huntingdon County 1800 census, twenty-two names after Christley Simmerman. ${ }^{79}$

- Jacob Schellenberger had married Elizabeth Keller, and was tabulated immediately after Philip as Jacob Shelleberger. ${ }^{80}$

The Harnisch brothers arrived at different times. Tobias Harness was in Morris Township, Huntingdon County by the time the 1800 census was taken. ${ }^{81}$ Although one county history states that Christian Harnisch arrived in $1800,{ }^{82}$ and another that he arrived in $1790,{ }^{83}$ he sold land in York County on 26 March 1802, ${ }^{84}$ and thus probably arrived in Huntingdon County in 1802 or later. In addition to being a co-executor of Christian Zimmerman's will in 1805, he petitioned the Orphans' Court in 1808 for assignment of guardians for Zimmerman's minor child under fourteen and grandchildren. ${ }^{85}$ He was listed there as C. Harness in the 1810 census. ${ }^{86}$ His will was written on 15 September 1832 while a resident of Morris Township, and it was proved on 23 May $1839 .{ }^{87}$

\section{Dauphin, Berks, and Lancaster counties}

Baptism records for three of Christian Zimmerman's older daughters have been found, and they point the way toward the mother of Margaret.

- Maria Margaretha, whose parents were Christian Zimmerman and wife Maria Catharina, was born on 2 October 1780 and baptized on 12 November 1780 by Rev. John Waldschmidt. The sponsors were the baby's parents. ${ }^{88}$ The baby's name and birthdate are consistent with her name and calculated birth year engraved on her Ohio gravestone (died in 1843 at age 61 or 62). She was sixty-two when she died. This solidifies the conclusion that Christian Zimmerman's daughter, Margaret, married John Champion. Her call name of Margaretha, or Margaret, was used on her baptism record, in her father's will, and in her husband's will, but her gravestone engraver Americanized her name as Mary M. It is now known that the name of Margaret (Zimmerman) Champion's mother was Maria Catharina -?-. Daughter Margaret was about twenty-five years old when her father, Christian Zimmerman, died in 1805.

- Elizabeth, daughter of Christian Zimmerman and Catharina, born on 8 April 1782, was baptized on 18 August 1782, at the Quitapohila (Hill) Evangelical Lutheran Church in North Annville Township, Lancaster County. ${ }^{89}$ Elizabeth was about twenty-three years old when her father died in 1805.

- Catharina, daughter of Christian and Catharina Zimmerman, was born on 15 April 1784, and baptized on 30 June 1784 , also at Quitapohila (Hill) Evangelical Lutheran Church. ${ }^{90}$ Catharina was deceased when her father died in $1805 .{ }^{91}$

No baptism record of Christiana has been located. Because Christian Zimmerman's older children were listed in order by age, and Christiana was listed fourth, she was probably the youngest daughter by mother Maria Catharina. Christiana was single as of 1805 but at least fourteen years old in $1808 .^{92}$

No marriage record for Christian Zimmerman and Maria Catharina -?- has been located. A plausible marriage year range is $1779-80$ based on the birthdate of their first daughter Margaret. Christian's wife Maria Catharina -?- must have died before 15 December 1794 when Christian married Margaret Schellenberger. These clues lead to an identification of Margaret Champion's mother. Her birth surname was Rupp, and her parents were Johannes Martin Rupp and Maria Margaretha Frey. Her father, who died on 11 December 1801, was buried in Hill Lutheran Church Cemetery, near Cleona, Dauphin County, now Lebanon County. ${ }^{93}$ The reason for this identification follows.

Johannes Martin Rupp's will, written on 12 April 1796, was proved in Dauphin County on 10 March $1802 .{ }^{94}$ His residence was given as Lebanon Township. ${ }^{95} \mathrm{He}$ named his wife as Margaret, ${ }^{96}$ and he also named a deceased daughter, Maria Catharina, who had married Christian Zimmerman, and who had children who were not named in the will. ${ }^{97}$ Thus, Margaret (Zimmerman) Champion's mother was Maria Catharina Rupp (see Figure 6).

Johannes Martin Rupp married Maria Margaretha Frey on 20 May 1750 at Muddy Creek Church in Cocalico Township, Lancaster County. ${ }^{98}$ Maria Catarina Rupp, future wife of Christian Zimmerman, was born on 26 February 1750/51, and baptized on 24 March 1750/51, at the same church. ${ }^{99}$ Thus, Maria Catharina was almost certainly the first child of Johannes Martin Rupp and Maria Margaretha Frey. Following the American custom, Johannes Martin appears as John in most American records. He arrived in America on the ship Phoenix in Philadelphia on 15 September $1749 .{ }^{100}$ 


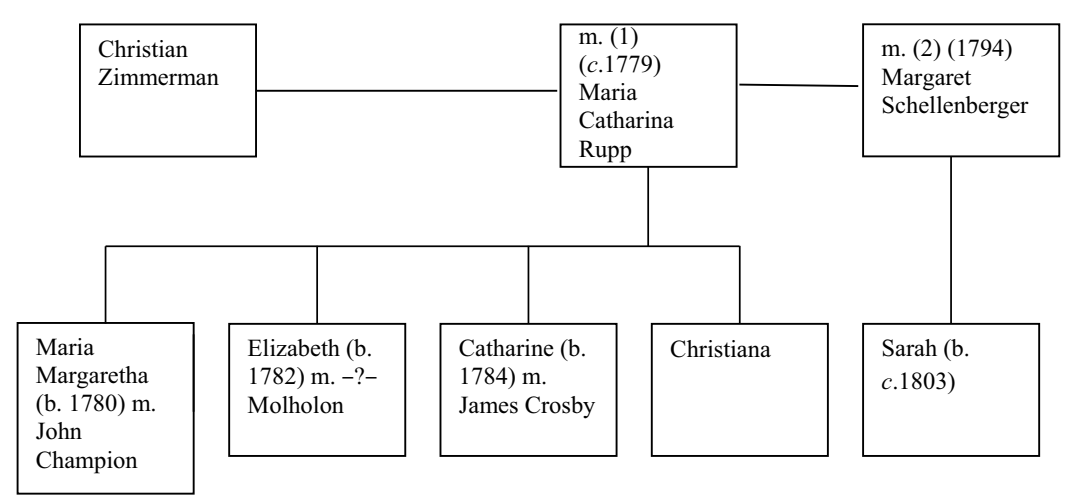

Figure 6. Christian Zimmerman's family.

Christian Harnisch was baptized on 1 May 1784 at the age of twenty, along with a son (Abraham) in Berks County, and the baptismal record names his father as Samuel. ${ }^{101}$ Christian Harnisch's father, Samuel, warranted land in Cocalico Township in Lancaster County in $1749^{102}$ and in $1758{ }^{103}$ as well as in Heidelberg Township in Lancaster County in $1745 .^{104}$ There was an early Cocalico connection between the Harnisches and Rupps. Moreover, Johannes Jacob Keller had also lived in Cocalico Township. ${ }^{105}$ That provides an explanation for why Philip Schellenberger, son of Johannes Michael Schellenberger of Cumru Township, married Maria Anna Keller, daughter of Johannes Jacob Keller of Heidelberg Township. Not only was there a Harnisch-Rupp connection earlier in Cocalico Township, but there was also a Harnisch-Keller connection there. As mentioned, Anna Catherina Keller, another daughter of Johannes Jacob Keller, married Tobias Harnisch, another son of Samuel. ${ }^{106}$ Also, Christian Zimmerman, first taxed in Cocalico Township in $1778,{ }^{107}$ probably married Maria Catharina Rupp there, as Catharina's father, usually appearing as John Rupp/Rup/Roop/Rupe, was taxed there as early as $1756^{108}$ and until at least $1777 .^{109}$

There is, however, another twist that made this extended family even more interconnected. Johannes [Jacob] Keller, father of the Keller daughters who married Schellenberger brothers, married Dorothea Rupp on 4 October 1772 (officiated by Rev. John Waldschmidt). ${ }^{110}$ Dorothea, born in January 1753 and baptized on 4 February 1753 at Muddy Creek Church, ${ }^{111}$ was a daughter of Johannes Martin Rupp and Margaretha Frey and therefore a sister of Christian Zimmerman's first wife, Maria Catharina Rupp. The Rupp, Schellenberger, Keller, and Harnisch families were interrelated multiple times by marriage. Christian Zimmerman's second wife was his first wife's sister's son-in-law's sister (Figure 7).

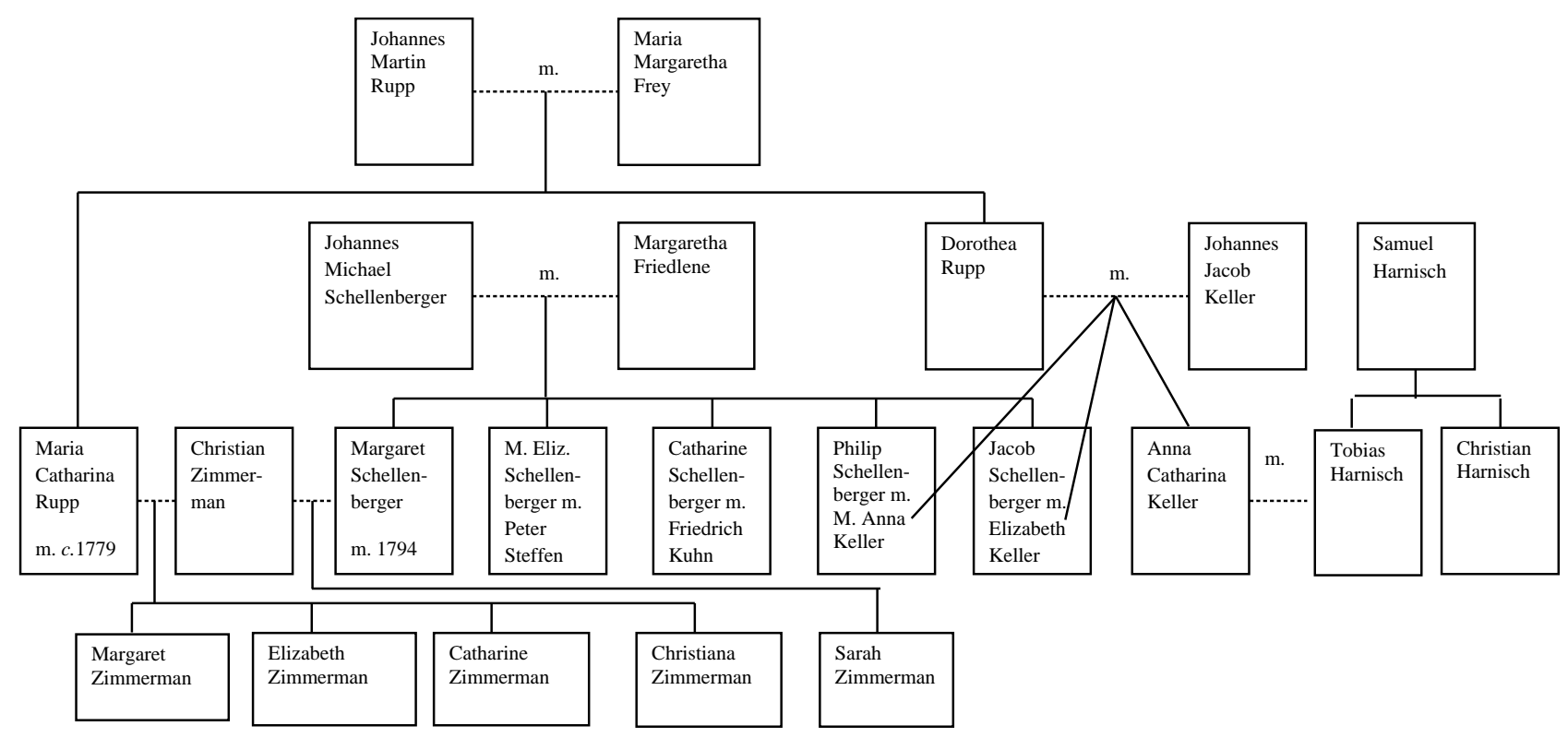

Figure 7. Family network. 


\section{Outline of feminist theory underlying the female connection method}

The female connection method is based on theoretical thinking about the critical role of women in families. In turn, that is based on philosophical analyses. Women give birth. ${ }^{112}$ They give the gift of life. A person, male or female, emerges into the world from a mother, interacts with the mother, and by virtue of the mother giving birth is born into relations, ${ }^{113}$ and lives with others. ${ }^{114}$ One is a "being-togetheramong-many, ${ }^{\prime 115}$ a point stressed by some feminist philosophers. ${ }^{116}$ This connects closely to philosopher Edmund Husserl's thoughts ${ }^{117}$ about being born into an ancestral heritage. ${ }^{118}$ A woman's identity is altered in response to the child. In intimate symbiotic relation with the child, the format and framing of the mother's space and especially time transform into responsibility for another person, her child. ${ }^{119}$ Over the course of the child's development, the mother helps the child become part of the immediate and larger family. Also, giving birth and relating to the child bring the mother into a relation not only with the next generation (which the child literally is) but with the previous one. ${ }^{120}$ She rerelates to her own birth mother, and implicitly with the chain of past generations. ${ }^{121}$ The living extended family grows as marriages bind family units together, and a new sense of belonging grows through female connections within the resulting network. The sense of belonging is one of comfort, familiarity, and reliance on each other for mutual support. Network members cooperate to complete arduous tasks, witness each other's legal documents, and commiserate during times of family tragedies. The extended family is a tight-knit circle from within which marriage partners are sometimes chosen. Even a mother's identity changes, becoming expressed through relations to others. ${ }^{122}$ Of course, the degree to which this happens varies by era, place, and culture, but these concepts and phenomena may be observed in a number of settings of genealogical interest.

The theoretical understanding of women's role in birth, family, and lineage leads to the important observation that women often fill the role of social connectors, taking on the responsibility for the social aspect of family connections and relations. Among those who have written about this are Chodorow, ${ }^{123}$ Mazey, ${ }^{124}$ Antonucci, ${ }^{125}$ and Smith. ${ }^{126}$ Often women pass on family narratives more than men. They tell and retell stories to their children to pass on traditions and family values that perpetuate the sense of belonging and further cement family bonds. Often women more than men are critical to binding families together, and build networks of families joined by marriage. Historically, men's social relations with other men were frequently formed in the context of business, employment, and military settings. Their social relations with men in an extended family often were based on connections established by women. Thus men were connected to society as producers and participants in public affairs while women practiced social connections unrelated to work or citizenship. ${ }^{127}$ Women's public affairs were generally limited to church attendance. ${ }^{128}$ (For genderless comments about kinsfolk who serve as links, see Jeanette Edwards. ${ }^{129}$ )

Applying these concepts to the practicalities of doing genealogical research, and especially in research focused on female ancestors and research subjects living in relevant cultures and eras, one may sometimes solve these difficult problems by following inter-family network connections that hinge on women. By recognizing that often women are the social glue that creates and holds these families together in clusters, one may be able to solve such genealogical problems.

\section{Sociological theory of social networks}

Another important theoretical background to the female connection method, as well as to the FAN principle, is the sociological study of networks. In a study of a Norwegian parish, J. A. Barnes focused on the "mesh of the social network." ${ }^{130}$ This idea was founded on observations about social ties of friendship and acquaintance, some of which were between kinsmen/women, which people in the parish of Bremnes built up. $^{131}$

In 1978, Alvin W. Wolfe summarized how social network theory developed in anthropology. ${ }^{132}$ For Wolfe, the rise in network thinking rests on four key scholarly trends of the middle of the twentieth century. They are the interest in relations more than in things, the interest in process over form, focusing on phenomena rather than institutions, and constructing generative instead of functional models. Network analysis views relations among people as elementary phenomena and as processes that prove adaptable to changing circumstances. Wolfe's analysis is pertinent to genealogical research. Genealogical research subjects were human objects which as such existed in relation to other people (genealogical relations such as child-father) and to other kinds of objects (artifacts, for example). These relations reveal significant evidence about a research subject. Although a person relates to institutions, participation in events (phenomena, transactions) is more important in shaping someone. ${ }^{133}$ A person is always in motion, or in process of becoming - developing, changing, being affected by and affecting events even while also remaining a continuous unique individuality throughout life's experiences. ${ }^{134}$ Although genealogy focuses on what most researchers assume is an unchangeable past, understanding that past requires recognizing dynamism, generativity, and the processual nature of history and society.

For John Scott, the image of intertwined social relations formalized some fundamental concepts in sociology. ${ }^{135}$ The social mesh ties individuals together with invisible bonds. ${ }^{136}$ Social network analysis provides a frame of reference to explain many areas of sociological 
study, including community structure, group dynamics, informal business influence paths, labor markets, social stratification, and crime. It can explain and deepen understanding of networks of friends, associates, and neighbors, but also, together with feminist theory, applies to the female connection method in genealogical research. The task of the sociologist is to describe and explain patterns exhibited in the network of connections. ${ }^{137}$ The task of genealogy is to learn from a study of sociological writings about social networks so that genealogical research that follows these network paths can be more effective and lead to greater understanding.

Social networks may reveal not only familial relations, but linkages based on politics, religion, and occupation as well as neighborhoods. Network analysts sometimes graphically represent the networks in charts ${ }^{138}$ or diagrams ${ }^{139}$ though there are issues with trying to capture the complexity and interweaving of multiple networks. ${ }^{140}$ Those at the center of a social network may have greater social influence than those at the periphery. ${ }^{141}$

\section{Female connections without FAN}

The objective of the female connection method is to identify hinge pins, or links, of a social network that often consists largely of an extended family joined by marriage(s). In many of these extended-family social networks, women are the links that establish and maintain the network. The female connection method seeks to discover the women who were the drivers of the building-out of the network and thus explain why the social web exists.

In this case study, it was brought to light that the Huntingdon County, Pennsylvania associates were Christian Zimmerman, John Keller, Tobias Harnisch, Christian Harnisch, Philip Schellenberger, Jacob Schellenberger, Peter Steffen, and Friedrich Kuhn. All were men. But women explain the reason why each is a member of this FAN group with the exception of Christian Harnisch (Table 1).

Table 1. FAN members and female links.

\begin{tabular}{ll}
\hline FAN member & Female reason(s)/links \\
\hline Christian Zimmerman & First wife Maria Catharine Rupp \\
& Second wife Margaret Schellenberger \\
John Keller & Wife Dorothea Rupp (sister of Maria Catharine (Rupp) Zimmerman \\
Tobias Harnisch & Wife Anna Catharine Keller (daughter of Dorothea (Rupp) Keller) \\
Christian Harnisch & Brother of Tobias Harnisch \\
Philip Schellenberger & Wife Maria Anna Keller (sister-in-law of Margaret (Schellenberger) Zimmerman) \\
Jacob Schellenberger & Wife Elizabeth Keller (sister-in-law of Margaret (Schellenberger) Zimmerman) \\
Peter Steffen & Wife Maria Elizabeth Schellenberger (sister of Margaret (Schellenberger) Zimmerman) \\
Friedrich Kuhn & Wife Catharine Schellenberger (sister of Margaret (Schellenberger) Zimmerman) \\
\hline
\end{tabular}

The women connectors of the network were sisters and sisters-in-law:

- Maria Catharine Rupp and Dorothea Rupp;

- Margaret Schellenberger, Maria Elizabeth Schellenberger, and Catharine Schellenberger;

- Maria Anna Keller, Elizabeth Keller, and Anna Catharine Keller; and

- Maria Anna Keller and Elizabeth Keller were sisters-in-law of Margaret (Schellenberger) Zimmerman, Maria Elizabeth (Schellenberger) Steffen, and Catharine (Schellenberger) Kuhn.

In this case study, from a research perspective, the network reconstruction began with Margaret Schellenberger (Christian Zimmerman's second wife). Through her father's will, her sisters were identified as:

- Maria Elizabeth Schellenberger who married Peter Steffen, and

- Catharine Schellenberger who married Friedrich Kuhn.

Also through her father's will, her brothers were identified as:

- Philip Schellenberger, and

- Jacob Schellenberger. 
Researching the brothers led to identification of their wives:

- Maria Anna Keller, and

- Elizabeth Keller,

who through their father's will were discovered to be sisters. Their mother was Dorothea Rupp, whose father's will led to her sister, Maria Catharina Rupp, who was the first wife of Christian Zimmerman.

The method consists of finding closely related females (often sisters, but sometimes sisters-in-law, mothers-daughters, and aunts-nieces) that form the foundation of a social network, often comprising an extended family network. The network is frequently formed by joining families by marriage, and at the heart of the network are critical links who in many cases are women.

\section{Conclusions}

The research goal of identifying Margaret (Zimmerman) Champion's mother can be achieved using a combination of direct evidence and the FAN method. Another method is to combine direct evidence with the female connection method. In this case as in others, females were essential in connecting families together. Often they were the glue, or connecting points, of the interconnected family network. Research to solve the quest for a specific female ancestor followed these female interconnecting points. Sisters, sisters-in-law, mothers, and daughters linked the various family units into a large network that was reconstructed through research by following these female connections. (In other cases, aunts, nieces, grandmothers, and granddaughters may be connectors.) For example, a Keller daughter brought the Harnisch brothers into the network. Keller sisters married Schellenberger brothers, and brought their husbands and two sisters-in-law (Maria Elizabeth Schellenberger and Catharine Schellenberger) into the grand network together with their husbands, Friedrich Kuhn and Peter Steffen. In the end, it was discovered that Christian Zimmerman's first wife's (Maria Catharina Rupp) sister's (Dorothea [Rupp] Keller) daughters' (Maria Anna [Keller] Schellenberger and Elizabeth [Keller] Schellenberger) sister-in-law (Margaret Schellenberger) became Christian Zimmerman's second wife.

While the end genealogical goal of this research was to discover who Margaret (Zimmerman) Champion's mother was, the initial preliminary goal was to discover who Christian Zimmerman's widow was. That enabled confirmation that the widow was not Margaret's mother. Also the widow was the first key female who led the way toward discovering connections that ultimately led to the end goal. Female linkages were crucial to unraveling this puzzle. Not every problem involving tracing the ancestry of female (and male) research subjects may be solved using the female connection method. Some families were small and relatively socially isolated, some were interconnected primarily by males, and for others evidence is insufficient to reconstruct a social network. However, there are some cases that may be solved using this method, and this approach may also work to supplement other research strategies. Moreover, understanding these connections often brings better insight into networked family structures and relations. This method may also result in more effective research.

There are two important differences between the methods used in this article. First, the FAN approach focuses primarily on men, largely because their associations are better documented. In this case, the crucial FANs are Christian Zimmerman, John Keller, Philip Schellenberger, Jacob Schellenberger, Tobias Harnisch, Christian Harnisch, Peter Steffen, and Friedrich Kuhn. But almost all of these FANs are such because they are connected to the network by females: Maria Catharina and Dorothea Rupp, Maria Anna, Elizabeth, and Anna Catharina Keller, and Margaret, Maria Elizabeth, and Catharine Schellenberger. One understands the reasons for the network better if one approaches the network through female connections (shown in bold):

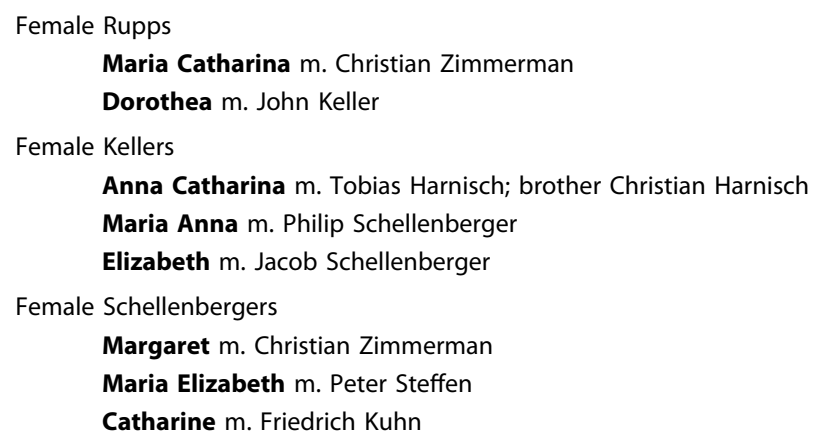


Second, the female connection method works because of the social forces at play in constructing and maintaining networks, while the FAN method, because of patriarchal customs and rules, works with symptoms, effects, or relations resulting from the underlying female connection network. The female connection method results in valuable insight into family network dynamics.

\section{Citation information}

Cite this article as: Hatton, Stephen B. (2018) Female connection method: using a socia network approach to genealogical research in the search for the mother of Margare Champion. Journal of Genealogy and Family History. 2(1). http://dx.doi.org/10.24240/ 23992964.2018.1234516.

\section{References}

1. Mills, Elizabeth Shown. (2012) QuickSheet: the historical biographer's guide to cluster research. Baltimore: Genealogical Publishing.

2. Testamentary records. USA. 7 November 1805. ZIMMERMAN, Christian. Will. Register of Wills. Huntingdon County, Pennsylvania. Vol. 1, p. 290. https://www. familysearch.org.

3. Testamentary records. USA. 7 November 1805. ZIMMERMAN, Christian. Will. Register of Wills. Huntingdon County, Pennsylvania. Vol. 1, p. 293. https://www. familysearch.org.

4. Testamentary records. USA. 7 November 1805. ZIMMERMAN, Christian. Will. Register of Wills. Huntingdon County, Pennsylvania. Vol. 1, p. 290. https://www. familysearch.org.

5. Testamentary records. USA. 7 November 1805. ZIMMERMAN, Christian. Will. Register of Wills. Huntingdon County, Pennsylvania. Vol. 1, p. 290. https://www. familysearch.org.

6. Testamentary records. USA. 3 March 1817. CHAMPION, James. Will. Register of Wills. Beaver County, Pennsylvania. Vol. A, p. 117. https://www.familysearch.org.

7. Census. 1800. USA. Morris Township, Huntingdon County, Pennsylvania. p. 148. National Archives and Records Administration. Microfilm M32, roll 40.

8. Testamentary records. USA. 3 March 1817. CHAMPION, James. Will. Register of Wills. Beaver County, Pennsylvania. Vol. A, p. 117. https://www.familysearch.org.

9. Monumental inscriptions. USA. Hanna Cemetery, Crawford County, Ohio. 10 August 1826. CHAMPION, John. Memorial 8900204. www.findagrave.com.

10. Monumental inscriptions. USA. Hanna Cemetery, Crawford County, Ohio. 10 August 1826. CHAMPION, John. Memorial 8900204. www.findagrave.com.

11. Testamentary records. USA. 29 July 1826. CHAMPION, John. Will. Probate Court. Administration Record. Vol. 1, p. 208. Richland County, Ohio. https://www.family search.org.

12. Monumental inscriptions. USA. Hanna Cemetery, Crawford County, Ohio. 27 January 1843. CHAMPION, Mary M. Memorial 8900221. www.findagrave.com.

13. Monumental inscriptions. USA. Hanna Cemetery, Crawford County, Ohio. 27 January 1843. CHAMPION, Mary. M. Memorial 8900221. www.findagrave.com.

14. Testamentary records. USA. 7 November 1805. ZIMMERMAN, Christian. Will. Register of Wills. Huntingdon County, Pennsylvania. Vol. 1, p. 289. https://www. familysearch.org.

15. Testamentary records. USA. 7 November 1805. ZIMMERMAN, Christian. Will. Register of Wills. Huntingdon County, Pennsylvania. Vol. 1, p. 290. https://www. familysearch.org.

16. Testamentary records. USA. 7 November 1805. ZIMMERMAN, Christian. Will. Register of Wills. Huntingdon County, Pennsylvania. Vol. 1, p. 290. https://www. familysearch.org.

17. Testamentary records. USA. 3 May 1808. ZIMMERMAN, Christian. Orphans' Court. Orphans' Court Docket. Huntingdon County, Pennsylvania. Vol. B, p. 134, file F, no. 65. https://www.familysearch.org.

18. Testamentary records. USA. 3 May 1808. ZIMMERMAN, Christian. Orphans' Court. Orphans' Court Docket. Huntingdon County, Pennsylvania. Vol. B, p. 135, file F, no. 65. https://www.familysearch.org.

19. Testamentary records. USA. 7 November 1805. ZIMMERMAN, Christian. Will. Register of Wills. Huntingdon County, Pennsylvania. Vol. 1, p. 290. https://www. familysearch.org.

20. Testamentary records. USA. 3 May 1808. ZIMMERMAN, Christian. Orphans' Court. Orphans' Court Docket. Huntingdon County, Pennsylvania. Vol. B, pp. 134-35, file F, no. 65. https://www.familysearch.org.

21. Testamentary records. USA. 7 November 1805. ZIMMERMAN, Christian. Will. Register of Wills. Huntingdon County, Pennsylvania. Vol. 1, p. 289. https://www. familysearch.org.

22. Recorder (USA). David and Elizabeth STEWART, James and Jane STEWART, Hugh and Mary MCKILLIP, Jacob and Catharine WHITZEL to Christian ZIMMERMAN. 30 June 1798. Deeds. Huntingdon County, Pennsylvania. Vol. L-1, p. 462. https://www. familysearch.org.
23. Testamentary records. USA. 7 November 1805. ZIMMERMAN, Christian. Will. Register of Wills. Huntingdon County, Pennsylvania. Vol. 1, p. 290. https://www.familysearch.org.

24. Testamentary records. USA. 3 May 1808. ZIMMERMAN, Christian. Orphans' Court. Orphans' Court Docket. Huntingdon County, Pennsylvania. Vol. B, p. 134, file F, no. 65. https://www.familysearch.org.

25. Census. 1800. USA. Morris Township, Huntingdon County, Pennsylvania. p. 148. National Archives and Records Administration. Microfilm M32, roll 40.

26. Recorder (USA). David and Elizabeth STEWART, James and Jane STEWART, Hugh and Mary MCKILLIP, Jacob and Catharine WHITZEL to Christian ZIMMERMAN. 30 June 1798. Deeds. Huntingdon County, Pennsylvania. Vol. L-1, p. 461. https://www. familysearch.org.

27. Census. 1800. USA. Morris Township, Huntingdon County, Pennsylvania. p. 148. National Archives and Records Administration. Microfilm M32, roll 40.

28. Recorder (USA). David and Elizabeth STEWART, James and Jane STEWART, Hugh and Mary MCKILLIP, Jacob and Catharine WHITZEL to Christian ZIMMERMAN. 30 June 1798. Deeds. Huntingdon County, Pennsylvania. Vol. L-1, p. 461. https://www. familysearch.org.

29. Testamentary records. USA. 7 November 1805. ZIMMERMAN, Christian. Will. Register of Wills. Huntingdon County, Pennsylvania. Vol. 1, p. 290. https://www. familysearch.org.

30. Census. 1800. USA. Morris Township, Huntingdon County, Pennsylvania. p. 148. National Archives and Records Administration. Microfilm M32, roll 40.

31. Recorder (USA). David and Elizabeth STEWART, James and Jane STEWART, Hugh and Mary MCKILLIP, Jacob and Catharine WHITZEL to Christian ZIMMERMAN. 30 June 1798. Deeds. Huntingdon County, Pennsylvania. Vol. L-1, pp. 461-62. https:// www.familysearch.org.

32. Census. 1800. USA. Morris Township, Huntingdon County, Pennsylvania. p. 148. National Archives and Records Administration. Microfilm M32, roll 40.

33. Recorder (USA). Christian ZIMMERMAN to Frederick KUHN. 26 October 1801. Deeds. Huntingdon County, Pennsylvania. Vol. I-1, p. 492. https://www.familysearch.org.

34. Recorder (USA). Christian ZIMMERMAN to Frederick KUHN. 26 October 1801. Deeds. Huntingdon County, Pennsylvania. Vol. I-1, p. 492. https://www.familysearch.org.

35. Census. 1800. USA. Morris Township, Huntingdon County, Pennsylvania. p. 149. National Archives and Records Administration. Microfilm M32, roll 40.

36. Testamentary records. USA. 7 November 1805. ZIMMERMAN, Christian. Will. Register of Wills. Huntingdon County, Pennsylvania. Vol. 1, p. 290. https://www. familysearch.org.

37. Census. 1800. USA. Morris Township, Huntingdon County, Pennsylvania. p. 149. National Archives and Records Administration. Microfilm M32, roll 40.

38. Testamentary records. USA. 7 November 1805. ZIMMERMAN, Christian. Will. Register of Wills. Huntingdon County, Pennsylvania. Vol. 1, p. 290. https://www. familysearch.org.

39. Census. 1800. USA. Morris Township, Huntingdon County, Pennsylvania. p. 149. National Archives and Records Administration. Microfilm M32, roll 40.

40. Testamentary records. USA. 3 May 1808. ZIMMERMAN, Christian. Orphans' Court. Orphans' Court Docket. Huntingdon County, Pennsylvania. Vol. B, p. 135, file F, no. 65. https://www.familysearch.org.

41. Census. 1800. USA. Morris Township, Huntingdon County, Pennsylvania. p. 149 National Archives and Records Administration. Microfilm M32, roll 40.

42. Recorder (USA). David and Elizabeth STEWART, James and Jane STEWART, Hugh and Mary MCKILLIP, Jacob and Catharine WHITZEL to Christian ZIMMERMAN. 30 June 1798. Deeds. Huntingdon County, Pennsylvania. Vol. L-1, pp. 461-64. https:// www.familysearch.org.

43. Recorder (USA). David and Elizabeth STEWART, James and Jane STEWART, Hugh and Mary MCKILLIP, Jacob and Catharine WHITZEL to Christian ZIMMERMAN. 30 June 1798. Deeds. Huntingdon County, Pennsylvania. Vol. L-1, p. 462. https://www. familysearch.org.

44. Africa, J. Simpson. (1883) History of Huntingdon and Blair Counties, Pennsylvania. Philadelphia: Louis H. Everts. p. 59.

45. Dauphin County, Pennsylvania, USA. Militia return rolls. April-May 1786, Christian Zimmerman (Vol. 3, p. 406); 19 October 1786, Christian Simmerman (Vol. 3, p. 407); Spring 1787, Christian Zimmerman (Vol. 3, p. 409); Fall 1787, Christian Zimmerman (Vol. 3, p. 389); Spring 1788, Christian Zimmerman (Vol. 3, p. 390); Fall 1788, Christian Zimmerman (Vol. 3, p. 392); and 27 October 1789, Chrestian Zimmerman (Vol. 3, p 373). Montgomery, Thomas Lynch. (1907) Pennsylvania Archives. 6th series. Harrisburg: Harrisburg Publishing Company. 
46. Board of Commissioners (USA). Dauphin County, Pennsylvania. Tax Rates. 1785 (image 14, Christian Zemerman); 1786 (image 23, Christley Simmerman); 1787 (image 29, Christian Simoron); 1789 (image 32, Christn Simmerman); 1791 (image 37, Christian Simmerman); 1793 (image 42, Cristian Simmerman). Family History Library microfilm 21,305. https://www.familysearch.org.

47. Marriages. USA. Campbelltown, Londonderry Township, Dauphin County, Pennsylvania. 15 December 1794. Evangelical Lutheran Church. ZIMMERMAN, Christian and SHELLEBERGER, Margaretha. Lutheran Archives Center, Philadelphia, Pennsylvania.

48. Monumental inscriptions. USA. Hanna Cemetery, Crawford County, Ohio. 12 December 1868. CHAMPION, Christian. Memorial 8866229. www.findagrave.com.

49. The Holy Bible. (1833) New York: B. Waugh and T. Mason. Photocopy in possession of author.

50. Baptisms. USA. Cocalico Township, Lancaster County, Pennsylvania. 31 July 1780. Muddy Creek Church. STEFFY, Elizabeth. p. 33. Evangelical and Reformed Historical Society, Lancaster, Pennsylvania.

51. Wright, F. Edward. (1999) Lancaster County, Pennsylvania church records of the 18th century. Westminster: Willow Bend Books. Vol. 1. p. 170.

52. Marriages. USA. Reading, Berks County, Pennsylvania. 8 December 1789. Trinity Lutheran Church. KUHN, Friedrich and SCHELLENBERGER, Catharina. Image 497, number 27. Family History Library microfilm 22,035, item 3. https://www.family search.org.

53. Marriages. USA. Reading, Berks County, Pennsylvania. 8 December 1789. Trinity Lutheran Church. KUHN, Friedrich and SCHELLENBERGER, Catharina. Image 497 number 27. Family History Library microfilm 22,035, item 3. https://www.family search.org

54. Marriages. USA. Reading, Berks County, Pennsylvania. 8 December 1789. Trinity Lutheran Church. KUHN, Friedrich and SCHELLENBERGER, Catharina. Image 497 number 27. Family History Library microfilm 22,035, item 3. https://www.family search.org.

55. Baptisms. USA. Heidelberg Township, Berks County, Pennsylvania. 15 May 1791. St. John's (Hain's) Reformed Church. Copied by William J. Hinke. KUHN, Anna Margaretha. Image 203. Family History Library microfilm 20,350, item 3. https:// www.familysearch.org.

56. Baptisms. USA. Reading, Berks County, Pennsylvania. 30 January 1793. Trinity Lutheran Church. KUHN, Rahel. Image 400. Family History Library microfilm 22,035, item 3. https://www.familysearch.org.

57. Baptisms. USA. Exeter Township, Berks County, Pennsylvania. 3 May 1795. Schwartzwald Church. KUHN, Catharina. p. 72. Records of Johann Wilhelm Boos, translated by G. W. Unger and William H. Dietrich. Family History Library microfilm 22,052. https://www.familysearch.org.

58. Baptisms. USA. Exeter Township, Berks County, Pennsylvania. 9 February 1797 Schwartzwald Church. KUHN, Johannes. p. 79. Records of Johann Wilhelm Boos, translated by G. W. Unger and William H. Dietrich. Family History Library microfilm 22,052. https://www.familysearch.org

59. Testamentary records. USA. 16 May 1800. SHELLENBERGER, Michael. Will. Registe of Wills. Berks County, Pennsylvania. Vol. 3, pp. 298-99. https://www.familysearch. org.

60. Testamentary records. USA. 7 November 1805. KELLER, John. Will. Register of Wills. Huntingdon County, Pennsylvania. Vol. 3, pp. 338-39. https://www.family search.org.

61. Testamentary records. USA. 16 May 1800. SHELLENBERGER, Michael. Will. Register of Wills. Berks County, Pennsylvania. Vol. 3, pp. 298-99. https://www. familysearch.org.

62. Census. 1800. USA. Morris Township, Huntingdon County, Pennsylvania. p. 148 National Archives and Records Administration. Microfilm M32, roll 40.

63. Monumental inscriptions. USA. Keller Church Cemetery, Yellow Spring, Blair County, Pennsylvania. 1 May 1832. SHELlEnBERGER, Anna Maria. Memorial 71308033. Www.findagrave.com.

64. Census. 1840. USA. Monroe Township, Richland County, Ohio. p. 83. National Archives and Records Administration. Microfilm M704, roll 423.

65. Monumental inscriptions. USA. Saint John Cemetery, Perrysville, Richland County, Ohio. 29 November 1843. SHELLENBARGER, Philip. Memorial 29124603. www. findagrave.com.

66. Marriages. USA. Reading, Berks County, Pennsylvania. 14 December 1794. Trinity Lutheran Church. SCHELLENBERGER, Jacob and KELLER, Elizabeth. Image 504, number 24. Family History Library microfilm 22,035, item 3. https://www.family search.org.

67. Montgomery, Thomas Lynch. (1907) Pennsylvania archives. Vol. 6. 6th series. Harrisburg: Harrisburg Publishing Company. p. 177.
68. Testamentary records. USA. 7 November 1805. KELLER, John. Will. Register of Wills. Huntingdon County, Pennsylvania. Vol. 3, pp. 338-39. https://www.family search.org.

69. Wiley, Samuel T. and Garner, W. Scott, eds. (1892) Biographical and portrait cyclopedia of Blair County, Pennsylvania. Philadelphia: Gresham Publishing Company. p. 466

70. Testamentary records. USA. 1 July 1788. HARNISH, Samuel. Will. Register of Wills. Lancaster County, Pennsylvania. German will of Samuel Harnish. Lancaster County Archives, Lancaster, Pennsylvania.

71. Testamentary records. USA. 1 July 1788. HARNISH, Samuel. Will. Register of Wills. Lancaster County, Pennsylvania. German will of Samuel Harnish. Lancaster County Archives, Lancaster, Pennsylvania.

72. Monumental inscriptions. USA. Keller Church Cemetery, Yellow Spring, Blair County, Pennsylvania. 17 December 1885. HARNISH, Tobias. Memorial 85766020; HARNISH, Catharine. Memorial 85766170. www.findagrave.com.

73. Testamentary records. USA. 10 March 1825. KELLER, John. Will. Register of Wills Huntingdon County, Pennsylvania. Vol. 3, pp. 338-39. https://www.family search.org.

74. Census. 1800. USA. Morris Township, Huntingdon County, Pennsylvania. p. 148. National Archives and Records Administration. Microfilm M32, roll 40.

75. Testamentary records. USA. 16 May 1800. SHELLENBERGER, Michael. Will. Register of Wills. Berks County, Pennsylvania. Vol. 3, pp. 298-99. https://www. familysearch.org.

76. Census. 1800. USA. Tyrone Township, Huntingdon County, Pennsylvania. p. 151 National Archives and Records Administration. Microfilm M32, roll 40.

77. Testamentary records. USA. STEFFEY, Peter. 23 April 1833. Will. Register of Wills. Huntingdon County Pennsylvania. Vol. 4, pp. 173-75. https://www.family search,.org.

78. Monumental inscriptions. USA. Shaffersville Cemetery, Shaffersville, Huntingdon County, Pennsylvania. 30 September 1837. KUHN, Frederick. Memorial 72543114. www.findagrave.com

79. Census. 1800. USA. Morris Township, Huntingdon County, Pennsylvania. p. 148 National Archives and Records Administration. Microfilm M32, roll 40.

80. Census. 1800. USA. Morris Township, Huntingdon County, Pennsylvania. p. 148. National Archives and Records Administration. Microfilm M32, roll 40.

81. Census. 1800. USA. Morris Township, Huntingdon County, Pennsylvania. p. 149. National Archives and Records Administration. Microfilm M32, roll 40.

82. Africa, J. Simpson. (1883) History of Huntingdon and Blair Counties, Pennsylvania. Philadelphia: Louis H. Everts. p. 322.

83. Commemorative biographical encyclopedia of the Juniata Valley, comprising the counties of Huntingdon, Mifflin, Juniata, and Perry, Pennsylvania. (1897) Chambersburg: J. M. Runk \& Co. p. 191.

84. Recorder (USA). Christian HARNISH to Peter SPRENKEL. 26 March 1802. Deeds. York County, Pennsylvania. Vol. 2Q, p. 475. https://www.familysearch.org.

85. Testamentary records. USA. 3 May 1808. ZIMMERMAN, Christian. Orphans' Court. Orphans' Court Docket. Huntingdon County, Pennsylvania. Vol. B, p. 135, file F, no. 65. https://www.familysearch.org.

86. Census. 1810. USA. Morris Township, Huntingdon County, Pennsylvania. p. 20 National Archives and Records Administration. Microfilm M252, roll 51

87. Testamentary records. USA. 15 September 1832. HARNISH, Christian. Will. Register of Wills. Huntingdon County, Pennsylvania. Vol. 4, pp. 137-39. https://www.famil ysearch.org.

88. Wright, F. Edward. (1993) Berks County, Pennsylvania church records of the 18th century. Westminster: Family Line Publications. Vol. 3. p. 195.

89. Baptisms. USA. North Annville Township, Lancaster (now Lebanon) County, Pennsylvania. 18 August 1782. Hill Lutheran Church. ZIMMERMAN, Elizabeth. Family History Library microfilm 1,434,020, item 2, p. 52. https://www.family search.org.

90. Baptisms. USA. North Annville Township, Lancaster (now Lebanon) County, Pennsylvania. 30 June 1784. Hill Lutheran Church. ZIMMERMAN, Catharina. Family History Library microfilm 1,434,020, item 2, p. 52. https://www.familysearch.org.

91. Testamentary records. USA. 7 November 1805. ZIMMERMAN, Christian. Will. Register of Wills. Huntingdon County, Pennsylvania. Vol. 1, p. 290. https://www. familysearch.org.

92. Testamentary records. USA. 3 May 1808. ZIMMERMAN, Christian. Orphans' Court. Orphans' Court Docket. Huntingdon County, Pennsylvania. Vol. B, pp. 134-35, file F no. 65. https://www.familysearch.org.

93. Monumental inscriptions. USA. Hill Church Cemetery, Cleona, Lebanon County, Pennsylvania. 11 December 1801. RUPP, Johannes Martin. Memorial 11264297. www.findagrave.com. 
94. Testamentary records. USA. 12 April 1796. RUPP, Johannes Martin. Will. Register of Wills. Dauphin County, Pennsylvania. Vol. 1B, pp. 91-93. https://www.family search.org.

95. Testamentary records. USA. 12 April 1796. RUPP, Johannes Martin. Will. Register of Wills. Dauphin County, Pennsylvania. Vol. 1B, p. 91. https://www.familysearch.org.

96. Testamentary records. USA. 12 April 1796. RUPP, Johannes Martin. Will. Register of Wills. Dauphin County, Pennsylvania. Vol. 1B, p. 92. https://www.familysearch.org.

97. Testamentary records. USA. 12 April 1796. RUPP, Johannes Martin. Will. Register of Wills. Dauphin County, Pennsylvania. Vol. 1B, p. 92. https://www.familysearch.org.

98. Records of pastoral acts of the Lutheran and Reformed congregations of the Muddy Creek Church, East Cocalico Township, Lancaster County, Pennsylvania, 1730-1790. (1981) Trans. William J. Hinke and Frederick S. Weiser. Breinigsville: The Pennsylvania German Society. p. 118.

99. Records of pastoral acts of the Lutheran and Reformed congregations of the Muddy Creek Church, East Cocalico Township, Lancaster County, Pennsylvania, 1730-1790. (1981) Trans. William J. Hinke and Frederick S. Weiser. Breinigsville: The Pennsylvania German Society. p. 74

100. Strassburger, Ralph Beaver and Hinke, William John. (1992) Pennsylvania German pioneers. Vol. 1. Camden: Picton Press. p. 407

101. Montgomery, Thomas Lynch. (1907) Pennsylvania archives. Vol. 6. 6th series. Harrisburg: Harrisburg Publishing Company. p. 170.

102. Records of the Land Office. Warrant number 470, p. 97, Samuel Harness, referencing warrant vol. $\mathrm{H}$, no. 36, p. 506 and survey book C111, p. 15 and survey book B13, p. 84; warrant for 250 acres on 10 May 1749, Warrant Register, Pennsylvania Historical and Museum Commission, RG-17. www.phmc.state.pa.us.

103. Records of the Land Office. Warrant number 611, p. 100, Samuel Harness, referencing warrant vol. H, no. 36, p. 424 and survey book C22, p. 22; warrant for 30 acres on 21 March 1758, Warrant Register, Pennsylvania Historical and Museum Commission, RG-17. www.phmc.state.pa.us.

104. Records of the Land Office. Warrant number 382, p. 94, Samuel Harnish, referencing warrant vol. H, no. 36, p. 506 and survey book C83, p. 262; warrant for 100 acres on 28 Nov 1745, Warrant Register, Pennsylvania Historical and Museum Commission, RG-17. www.phmc.state.pa.us.

105. Records of the Land Office. Warrant number 247, p. 117, Jacob Keller, referencing warrant vol. aa, no. 6, p. 66 and survey book C107, p. 154, warrant for 20 acres, 20 March 1753; warrant \#12, p. 112, John Keller, 28 February 1734; warrant \#149, p. 115, Heidelberg Township, 2 August 1746, Warrant Register, Pennsylvania Historical and Museum Commission, RG-17. www.phmc.state.pa.us.

106. Testamentary records. USA. 1 July 1788. HARNISH, Samuel. Will. Register of Wills. Lancaster County, Pennsylvania. German will of Samuel Harnish. Lancaster County Archives, Lancaster, Pennsylvania.

107. Board of Commissioners (USA). Lancaster County, Pennsylvania. Tax Records. 1778 Cocalico Township, Lancaster County, Pennsylvania. Taxes 1751-1808. FHL microfilm 1,449,272, image 214 (Christian Zimerman). https://www.familysearch.org.

108. Board of Commissioners (USA). Lancaster County, Pennsylvania. Tax Records. 1756 Cocalico Township, Lancaster County, Pennsylvania. Taxes 1751-1808. FHL microfilm 1,449,272, image 21 (John Rupp). https://www.familysearch.org.

109. Board of Commissioners (USA). Lancaster County, Pennsylvania Tax Records. 1756 Cocalico Township, Lancaster County, Pennsylvania. Taxes 1751-1808. FHL microfilm 1,449,272, image 199 (John Rupe). https://www.familysearch.org.

110. Montgomery, Thomas Lynch. (1907) Pennsylvania archives. Vol. 6. 6th series Harrisburg: Harrisburg Publishing Company. p. 232.

111. Records of pastoral acts of the Lutheran and Reformed congregations of the Muddy Creek Church, East Cocalico Township, Lancaster County, Pennsylvania, 1730-1790. (1981) Trans. William J. Hinke and Frederick S. Weiser. Breinigsville: The Pennsylvania German Society. p. 75

112. Guenther, Lisa. (2006) The gift of the other: Levinas and the politics of reproduction. Albany: State University of New York Press. p. 1.

113. O'Byrne, Anne. (2004) Symbol, exchange, and birth: towards a theory of labour and relation. Philosophy and Social Criticism. 30(3). p. 369.
114. Guenther, Lisa. (2006) The gift of the other: Levinas and the politics of reproduction. Albany: State University of New York Press. pp. 2, 251

115. Nancy, Jean-Luc. (1993) The birth to presence. Trans. Brian Holmes. Stanford Stanford University Press, p. 33.

116. Cavarero, Adriana. (2014) A child has been born unto us. Trans. Silvia Guslandi and Cosette Bruhns. Philosophia. 4. pp. 13, 23.

117. Husserl, Edmund. (1973) 'Zur Phänomenologie der Intersubjektivität: Texte aus dem Nachlass'. In: Kern, Iso, ed. Husserliana: Edmund Husserl - Gesammelte Werke. Vol. 15. The Hague: Martinus Nijhoff. p. 569.

118. Hatton, Stephen B. (2018) Family genealogy's contributions to the philosophical problem of birth. Genealogy. 2. p. 8. http://dx.doi.org/10.3390/genealogy/2020016.

119. Guenther, Lisa. (2006) The gift of the other: Levinas and the politics of reproduction. Albany: State University of New York Press. pp. 77, 129.

120. Guenther, Lisa. (2006) The gift of the other: Levinas and the politics of reproduction. Albany: State University of New York Press. pp. 99-100, 129.

121. Cavarero, Adriana. (1995) In spite of Plato: a feminist rewriting of ancient philosophy. Trans. Serena Anderlini-D'Onofrio and Áine O'Healy. New York: Routledge. p. 82.

122. Guenther, Lisa. (2006) The gift of the other: Levinas and the politics of reproduction. Albany: State University of New York Press. p. 100.

123. Chodorow, Nancy. (1978) The reproduction of mothering: psychoanalysis and the sociology of gender. Berkeley: University of California Press. pp. 135, 167, 175-78, 209.

124. Mazey, Mary Ellen and Lee, David R. (1983) Her space, her place: a geography of women. Washington: Association of American Geographers. p. 24.

125. Antonucci, Toni C (2001) 'Social relations: an examination of social networks, socia support and sense of control'. In: Binen, J. E. and Schnie, K. W., eds. Handbook of psychology of aging. San Diego: Academic Press. pp. 432-34.

126. Smith, Amy M. (2008) Family webs: the impact of women's genealogy research in family communication. PhD dissertation, Bowling Green State University.

127. De Beauvoir, Simone. (1949) The second sex. Trans. Constance Borde and Sheila Malovany-Chevallier. Reprinted 2011. New York: Vintage Books. pp. 571, 584.

128. Davidoff, Leonore and Hall, Catherine. (2002) Family fortunes. Rev. ed. London: Routledge. pp. 107-08.

129. Edwards, Jeanette and Strathern, Marylyn. (2000) 'Including our own'. In: Carsten, Janet, ed. Cultures of relatedness: new approaches to the study of kinship. Cambridge: Cambridge University Press. p. 153.

130. Barnes, J. A. (1954) Class and committees in a Norwegian island parish. Human Relations. 7. p. 54

131. Barnes, J. A. (1954) Class and committees in a Norwegian island parish. Human Relations. 7. p. 43

132. Wolfe, Alvin W. (1978) The rise of network thinking in anthropology. Social Networks. 1. p. 56.

133. Hatton, Stephen B. (2016) Thinking philosophically about genealogy. National Genealogical Society Quarterly. 104. pp. 5-18.

134. Hatton, Stephen B. (2016) Thinking about genealogical identity. National Genealogical Society Quarterly. 104. pp. 215-28.

135. Scott, John. (1988) Trend report: social network analysis. Sociology. 22. p. 109

136. Scott, John. (1988) Trend report: social network analysis. Sociology. 22. pp. 109-10.

137. Scott, John. (1988) Trend report: social network analysis. Sociology 22. p. 112

138. Scott, John. (1988) Trend report: social network analysis. Sociology. 22. pp. 109-27.

139. D'Cruze, Shani. (1994) 'The middling sort in eighteenth-century Colchester: independence, social relations and the community broker'. In: Barry, Jonathan and Brooks, Christopher, eds. The middling sort of people: culture, society and politics in England, 1550-1800. New York: St. Martin's Press. pp. 181-207.

140. Price, Frances V. (1981) Reading data: Only connect? Issues in charting social networks. Sociological Review. 29. pp. 283-312.

141. D'Cruze, Shani. (1994) 'The middling sort in eighteenth-century Colchester: independence, social relations and the community broker'. In: Barry, Jonathan and Brooks, Christopher, eds. The middling sort of people: culture, society and politics in England, 1550-1800. New York: St. Martin's Press. p. 190.

\section{ABOUT THE AUTHOR}

Stephen B. Hatton is interested in genealogical methodology, theory, and relations with other academic disciplines. He is a trustee of the Ohio Genealogical Society and published an article in volume 1 of The Journal of Genealogy and Family History.

Email: StephenHatton@archeopath.info 